\title{
ON POSSIBLE MECHANISMS OF ATMOSPHERIC FORMALDEHYDE EFFECT ON THE FORMATION OF THE POPULATION THYROID CANCER MORBIDITY
}

\author{
Chernichenko I.O., Balenko N.V., Tsymbaliuk S.N., Ostash O.M.
}

\section{ПРО МОЖЛИВВ МЕХАНІЗМИ ВПЛИВУ АТМОСФЕРНИХ ЗАБРУДНЕНЬ ФОРМАЛЬДЕГІДОМ НА ФОРМУВАННЯ ЗАХВОРНВВАНОСТІ НАСЕЛЕННЯ НА РАК ЩИТОПОДІБНӦ̈ ЗАЛОЗИ}

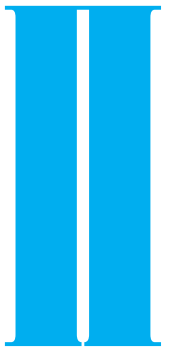

1ЧЕРНИЧЕНКО I.O.,

'БАЛЕНКО Н.В.

ЦИМБАЛЮК С.М.,

'ОСТАШ O.М.

'ДУ "Інститут

громадського здоров'я

ім. О.М. Марзєєва

НАМНУ", м. Київ

${ }^{2}$ Київський міський клінічний

ендокринологічний центр

УДК $614.71: 547.281 .1$

: $612.44: 616-006$

Ключові слова: щитоподібна залоза, пухлини,

формальдегід, механізми впливу. роведений нами аналіз динаміки захворюваності населення на злоякісні пухлини щитоподібної залози (ЩЗ) (за даними Національного канцер-реєстру) за 1991-2011 роки по всіх областях України показав більш високі рівні і щорічний приріст цієї патології у промислових регіонах та сільськогосподарських областях 3 інтенсивним використанням пестицидів порівняно $з$ ендемічними щодо йододефіциту територіями та зонами підвищеного радіаційного контролю [1]. В іншому дослідженні нами встановлено наявність прямого кореляційного зв'язку між забрудненням атмосферного повітря пріоритетними канцерогенними речовинами і захворюваністю населення на злоякісні пухлини взагалі та рак щитоподібної залози (Рщ3), зокрема [2].

Такі закономірності, на нашу думку, можуть свідчити про те, що у формуванні онкопатології ЩЗ, крім йододефіциту та радіаційного чинника, певну роль відіграють інші зовнішні фактори як хімічні забруднювачі довкілля, у тому числі канцерогенні сполуки.

До пріоритетних канцерогенів, що забруднюють атмосферне повітря, належить і формальдегід.

До того ж останнім часом у літературі з'явилися дані про підвищений ризик РЩЗ серед жінок, що працюють у текстильному виробництві, і його зв'язок з тривалою професійною експозицією до формальдегіду [3].

Мета цієї роботи - з'ясувати можливі механізми впливу формальдегіду на формування захворюваності населення на злоякісні пухлини ЩЗ.

Матеріали та методи. Аналіз власних та літературних даних. Використання методу теоретичного аналізу науково-методичної літератури (узагальнення, синтез та абстрагування) щодо особливостей біоефектів формальдегіду на організм та закономірностей їхнього прояву [4].

Результати та їх обговорення. Формальдегід (ФА) - сполука, якій притаманний широкий спектр біоефектів на організм. Залежно від рівня впливу ФА може спричинити загальнотоксичну, подразнювальну, сенсибілізуючу, алергенну дію, індукувати мутагенний та канцерогенний ефекти. Ці та інші питання докладно наведено у низці публікацій [5-9].
О ВОЗМОЖНЫХ МЕХАНИЗМАХ ВЛИЯНИЯ АТМОСФЕРНЫХ ЗАГРЯЗНЕНИЙ ФОРМАЛЬДЕГИДОМ НА ФОРМИРОВАНИЕ ЗАБОЛЕВАЕМОСТИ НАСЕЛЕНИЯ РАКОМ ЩИТОВИДНОЙ ЖЕЛЕЗЫ

1 Черниченко И.А., , 'Баленко Н.В., ${ }^{2}$ Цимбалюк С.Н., ${ }^{1}$ Осташ О.М. 1 ГУ «Институт общественного здоровья им. А.Н. Марзеева НАМНУ",

${ }^{2}$ Киевский городской клинический эндокринологический центр

Цель работы - выяснить возможные механизмы влияния формальдегида на формирование заболеваемости населения раком щитовидной железы. Материалы и методы. Анализ собственных и литературных данных. Использован метод теоретического анализа научно-методической литературы (обобщение, синтез и абстрагирование), касающийся биоэффектов этого соединения и закономерностей их проявления.

Результаты проведенного анализа показали, что формальдегид при ингаляционном поступлении может вызывать генотоксические и токсиче- ские повреждения в отдаленных от места первичного контакта тканях у людей и лабораторных животных (циркулирующие клетки крови, костный мозг). Кроме того, при совместном поступлении в организм с другими канцерогенами формальдегид активирует канцерогенез, а также усиливает иммуносупрессию. Эти данные позволяют предположить возможность индукции генотоксических и токсических изменении в щитовидной железе и их накопление при хроническом воздействии формальдегида совместно с другими канцерогенами атмосферных загрязнении, что в сочетании с иммуносупрессией может привести к усилению комбинированного эффекта и будет способствовать увеличению риска развития рака щитовидной железы среди населения. В условиях профессиональной экспозиции формальдегид может стать доминирующим фактором в формировании профессиональной заболеваемости раком щитовидной железы.

Ключевые слова: щитовидная железа, опухоли, формальдегид, механизмы влияния. 
ON POSSIBLE MECHANISMS OF ATMOSPHERIC FORMALDEHYDE EFFECT ON THE FORMATION OF THE POPULATION THYROID CANCER MORBIDITY Chernichenko I.O., Balenko N.V., Tsymbaliuk S.N., Ostash O.M.

State Institution "O.M. Marzeiev Institute for Public Health of the National Academy of Medical

Sciences of Ukraine",

Kyiv City Clinical Endocrinology Centre

Objective. We clarified possible mechanisms of the formaldehyde effect on the formation of the population thyroid cancer morbidity. Materials and methods. We analyzed our own data and literary ones with the help of the method of theoretical analysis (generalization, synthesis and abstraction) of the scientific and methodological literature on the biological effects of this compound and the regularities of their manifestation. Results. Formaldehyde inhalation can induce genotoxic and toxic damages in the tissues distant from the primary contact in humans and laboratory animals (circulating blood cells, bone marrow respectively). Furthermore, formaldehyde promotes a carcinogenesis and enhances an immunosupression at the joint administration with other carcinogens. According to these data an induction of genotoxic and toxic changes in thyroid gland and their accumulation at the chronic exposure of formaldehyde with other atmospheric carcinogens may be observed and in conjunction with the immunosupression it may lead to the strengthening of the combined effect and will increase the risk of thyroid cancer among population.

Under conditions of the occupational exposure formaldehyde can become a dominant factor in the formation of the professional thyroid cancer morbidity.

Keywords: thyroid gland, tumors, formaldehyde, mechanisms of the effect.
Порівняно недавно експерти МАВР рекласифікували ФА перевели з групи 2А до 1 групи, тобто до сполук, канцерогенних для людини. При цьому було вказано на достатність епідеміологічних доказів етіозв'язку раку носоглотки з експозицією ФА та наявність обмежених даних для лейкемії $[7,8]$.

Загалом відомо, що ФА $€$ дуже реакційно активною хімічною сполукою. Завдяки цьому він одразу після вдихання швидко зв'язується з біомолекулами і майже повністю абсорбується та метаболізується у верхніх відділах респіраторного тракту. У випадках високих концентрацій він може сягати більш глибоких відділів респіраторного тракту. Ще глибше проникнення можливе також у випадках надходження в абсорбованому стані на частинках пилу.

У місцях абсорбції ФА реагує з протеїнами, нуклеїновими кислотами, утворюючи ДНК-протеїнові комплекси. Основний шлях знешкодження - це утворення кон'югатів 3 глютатіоном за участі формальдегіддегідрогенази, альдегіддегідрогенази.

Тому зменшення кількості глютатіону, зумовлене ендогенними та екзогенними причинами, знижує можливості захисту слизової оболонки дихального шляху від утворення ДНК-протеїнових комплексів. У випадках надходження ФА у концентраціях, що перевищують можливості ендогенних захисних механізмів, відбувається утворення численних ДНК-протеїнових зшивок, що призводить до мутацій, зростання токсичності для клітин 3 наступною активацією проліферації.
У невеликій кількості ФА утворюється у живих організмах, у тому числі в організмі людини як продукт метаболізму амінокислот і ксенобіотиків. ФА фізіологічно присутній у рідкому середовищі, клітинах і тканинах організму. Ендогенна концентрація у крови людей, приматів та щурів становить приблизно 2-3 мг/л (0,1 mM) [9].

Відповідно до сучасної точки зору, що ґрунтується на численних експериментальних та епідеміологічних дослідженнях, здатність ФА утворювати ДНКпротеїнові комплекси та індукувати токсичні та генотоксичні ушкодження лежать в основі виникнення раку різних відділів верхнього респіраторного тракту людей і лабораторних тварин (раку носоглотки і носових синусів у людей, носової порожнини у лабораторних тварин (щурів, мишей)).

Локальні ефекти, генотоксичність і клітинна проліферація основні детермінанти, що визначають канцерогенність сполуки за інгаляційного надходження [8, 10].

Прийнято вважати, що ФА, завдяки високій реакційній здатності та швидкому метаболізму, не здатний до кумуляції, а його мутагенні та проліферативно-гіперпластичні ефекти у респіраторному тракті визначаються не сумарною (кумулятивною) дозою за тривалого надходження, а величиною концентрації, що вдихається у певний час.

Проте існують дані про більш тривалий напівперіод існування ДНК-адуктів формальдегіду в організмі порівняно 3 іншими адуктами, що дозволяє викори- стовувати їх наявність як біомаркер для оцінки внутрішньої дози канцерогена [8].

Водночас дослідження останніх років показали, що ФА за інгаляційного надходження до організму може викликати шкідливі ефекти не лише у місцях первинного контакту (респіраторний тракт), а й у віддалених органах і тканинах $[7,8]$. Це підтверджують епідеміологічні дані про генотоксичні та токсичні зміни у клітинах периферичної крови професійно експонованих осіб і їхній зв'язок з розвитком лейкемії, а також аналогічні зміни у кістковому мозку лабораторних тварин після інгаляції ФА.

У зв'язку з цими гіпотезами постало питання, яким чином високореакційний ФА може сягати клітин крови та тканин, які віддалені від місця первинного контакту.

Автори, у тому числі експерти MABP, аргументують таку можливість, виходячи 3 хімічних властивостей ФА, тобто здатності конвертуватися у присутності води у його діолову форму - метандіол $\left(\mathrm{CH}_{2}(\mathrm{OH})_{2}\right.$.

За припущенням авторів, ФА легко проникає у кров, а 3 током крови - у тканини та окремі органи.

Застосування низки біомаркерів дозволило встановити, що інгаляція ФА на рівні концентрацій $\left(0,5 ; 3,0 \mathrm{Mг} / \mathrm{M}^{3}\right)$ та тривалості впливу (8 годин/день, 5 днів/тиждень), аналогічних умовам професійної експозиції, спричиняє токсичний вплив на тканини кісткового мозку, що проявляється ознаками оксидативного стресу, запалення та апоптозу [11]. 


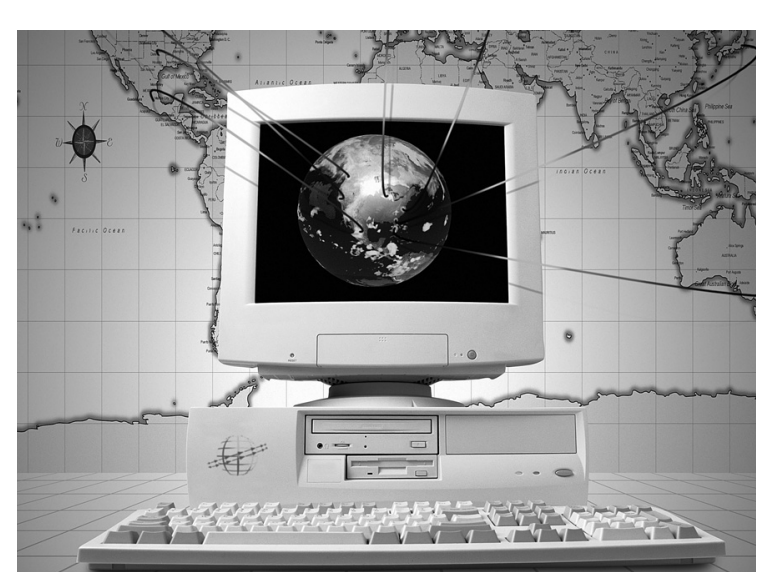

Ці зміни можливі, на думку авторів, за дії високих рівнів і можуть вести до зростання ризику захворювань гематопоетичної системи, зокрема анапластичної анемії, мієлодиспластичного синдрому. । навпаки, дія низьких концентрацій ФА індукує цитопротекторні реакції, що можуть нейтралізувати ці шкідливі ефекти. Дія високих рівнів стикається 3 недостатністю захисних механізмів в організмі, що сприяє розвитку патологічних змін.

При застосуванні методу токсикогеноміки було ідентифіковано гени та молекулярні сигнальні шляхи, які визначають чутливість організму до дії ФА, беруть участь у проявах токсичності та репарації ДНК-ушкоджень [12].

Численні експериментальні та епідеміологічні дослідження свідчать, що формальдегід $€$ загальновизнаним імунотоксикантом та активним алергеном [5-7, 9].

у недавньому повідомленні за матеріалами субхронічного досліду при інгаляції мурчакам ФА у різних дозах $(0,05 \pm 0,003)$ $\left.\mathrm{Mг} / \mathrm{M}^{3} ; \quad(0,13 \pm 0,004) \quad \mathrm{Mг} / \mathrm{M}^{3}\right)$ встановлено супресію Т-клітинної і гуморальної ланок імунітету, що проявилася, відповідно, зниженням кількості Т-лімфоцитів, Т-активних лімфоцитів, Т-хелперів, В-лімфоцитів, а також кількості IgA та IgG [13].

В епідеміологічних дослідженнях в осіб, експонованих до ФА за професійних умов, встановлено наявність формальдегідспецифічних антитіл IgE та IgG у сироватці крови дітей шкільного віку, які зазнавали дії ФА атмосферного повітря.

Як вже було вказано, в останнє десятиріччя 3'явилася інформація про ексцес раку щЗ серед жінок, які працюють на текстильному виробництві, і його зв'язок з професійним впливом формальдегіду [3].

Привертає увагу той факт, що з великої кількості експозиційних факторів хімічної та фізичної природи на цьому виробництві (близько 20 найменувань окремих факторів і їхніх груп метали, розчинники, пил різного складу і структури, органічні та неорганічні гази, електромагнітні випромінювання тощо), причинно-наслідковий зв'язок РЩЗ було встановлено лише 3 дією формальдегіду, а також бензолу при робочому стажі 10 i більше років.

\section{ФУНДАМЕ}

Враховуючи отримані результати, автори припускають можливість зростання ризику РЩЗ також серед працівників інших виробництв (взуттєвого, деревообробного, паперового, целюлозного тощо) внаслідок професійної експозиції до формальдегіду та бензолу, що потребує подальших досліджень та підтвердження.

Механізми впливу формальдегіду на ЩЗ нині практично не вивчені.

Поодинокі дослідження у цьому напрямку, на жаль, стосуються тільки перорального шляху надходження [15]. При цьому встановлено, що ФА (дози 5; 10; 15 мкг/кг ваги тіла) чинить токсичну дію на ЩЗ. У всіх тварин порівняно з контролем відзначено зменшення ваги Щ3, максимально - при дозах 10, 15 мкГ/Кг, що супроводжувалося регресією фолікулів (епітелію), зниженням рівня тиреогормонів і підвищенням рівня тиреостимулюючого гормону гіпофіза. На думку авторів, ці зміни пов'язані з порушенням внутрішнього середовища організму.

Наявна нині інформація щодо біоефектів ФА дозволяє припустити, що за інгаляційного надходження один із шляхів його впливу на формування онкозахворюваності населення на злоякісні пухлини ЩЗ може здійснюватися опосередковано через різні порушення функції імунної системи, які призводять до зниження опірності організму, у тому числі до канцерогенезу.

Незважаючи на відсутність кумуляції ФА в організмі постійна присутність його у середовищі певних виробництв та довкіллі створює умови для небезпечного безперервного та тривалого впливу на організм людини.

Ця обставина має особливо важливе значення 3 урахуванням того факту, що ФА у вироб- ничому середовищі і за умов інгаляційного надходження 3 забрудненим атмосферним повітрям діє у складі багатокомпонентного комплексу 3 іншими генотоксичними канцерогенами і може підсилювати їхній ефект як модифікатор канцерогенезу.

На користь цього свідчать результати наших експериментальних досліджень. Експеримент було проведено на білих безпородних щурах, яких піддавали хронічному затруєнню в інгаляційних камерах формальдегідом у різних концентраціях $(0,003 ; 0,03$; $0,3 \mathrm{mr} / \mathrm{m}^{3}$ ) ізольовано або одночасно з введенням в органи дихання бенз(а)пірену (БП) (сумарні дози 5,0; 0,1; 0,02 мг).

Не зупиняючись на повній характеристиці експерименту та отриманих результатів, які докладно висвітлено у попередніх публікаціях $[15,16]$, важливо навести основні встановлені при цьому закономірності.

Передусім необхідно відзначити, що ФА за одночасного надходження з БП до органів дихання спричинив модифікуючий ефект на канцерогенез, який проявився його активацією залежно від рівнів впливу цих сполук.

Так, максимальна активація канцерогенезу за показниками, що характеризують інтенсивність його прояву (зростання частоти, у тому числі злоякісних пухлин, полінеоплазій (синхронний розвиток пухлин декількох локалізацій), метастазування, скорочення латентного періоду розвитку), спостерігалася за дії найвищих у досліді

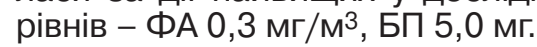
За інгаляції ФА у концентраціях 0,3 та 0,03 мг/ $\mathrm{M}^{3}$ одночасно 3 БП 0,1 мг та 5,0 мг спостерігалася тенденція до посилення канцерогенезу. До того ж важливо підкреслити, що модифікуючі концентрації ФА є значно 
нижчими, ніж рівні, що індукують пухлини у гризунів $(7,2$ $\mathrm{M} \Gamma / \mathrm{M}^{3}$ і вищі).

По-друге, привертає увагу також відмінність модифікуючого ефекту ФА від дії вивчених нами інших модифікаторів (оксидів азоту, фенолу, ортокрезолу) [15], яка полягала у стимулюванні канцерогенезу не тільки в органі-мішені (легенях), а й в інших органах за рахунок розширення спектра локалізацій первинних пухлин.

При цьому за сумісної дії ФА

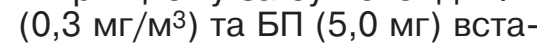
новлено розвиток пухлин 9 різних локалізацій, тоді як у контролі (ізольоване введення БП 5,0 мг) виникли пухлини лише 2-х локалізацій (молочна залоза, лімфолейкемія).

Серед пухлин позалегенової локалізації привертає увагу розвиток пухлин ендокринних органів, зокрема щЗ та частіше - молочної залози.

Паралельне вивчення імунологічних змін показало, що за комбінованої дії БП і ФА має місце імуномодулюючий ефект в окремих ланках імунної системи, який залежить від рівня і тривалості дії. Більш ніж адитивний ефект спостерігався у Т-системі імунітету за дії найвищих рівнів і проявився за типом супресії [17].

Згідно 3 іншим повідомленням, модифікуючий ефект ФА за одночасного з 7,12-диметилбенз(а)антраценом нанесення на шкіру мишам проявився скороченням латентного періоду розвитку пухлин шкіри [8].

Дані останнього десятиріччя стосовно причинного зв'язку лейкемії у людей з професійним впливом ФА та сучасні уявлення щодо механізмів і шляхів цього впливу наштовхують на думку про можливі інші механізми реалізації дії цієї сполуки на розвиток РЩЗ крім порушень Функцій імунної системи.

Визнаючи можливість надходження метандіолу до кров'яного русла, логічно припустити його потрапляння у щЗ, де він також може перебувати у стані рівноваги з ФА. Це створює умови для реакції ФА 3 біомолекулами клітин цього органу та утворення ДНК-протеїнових комплексів, виникнення мутацій та можливого прояву канцерогенезу за наявності інших сприятливих ендогенних та екзогенних факторів (генетична чутливість, спонтанні мутації, дія інших канцерогенів та наявність їхніх ефектів генетичних і епігенетичних ушкоджень, порушень репаративних процесів, локальних змін в органах - запальних, проліферативних, порушень функцій ендокринної системи та імунітету тощо).

За надходження низьких рівнів ФА, які спостерігаються у довкіллі, його вплив на розвиток пухлин ЩЗ можна прогнозувати як певний внесок у загальний канцерогенний ефект через дію складного комплексу хімічних забруднень атмосферного повітря. Таке припущення підтверджує спільний висновок експертів ВООЗ і ООН з оцінки хімічних руйнівників ендокринної системи, що ґрунтується на всебічному аналізі наукових джерел з цього питання [18].

Експерти наголошують на тому, що такі сполуки, незважаючи на відсутність ефекту за роздільного впливу на низьких рівнях, що визначаються у навколишньому середовищі, викликають суттєві порушення в ендокринній системі за комбінованого впливу. Ця обставина значною мірою ускладнює ідентифікацію ендокринних руйнівників і встановлення їхнього зв'язку з розвитком порушень та захворювань ендокринних органів.

Такий шлях реалізації канцерогенного впливу ФА на людей не можна виключити у випадках дії забруднень повітряного середовища на робочому місці у різних виробництвах і при забрудненні повітря приміщень та довкілля.

Цілком ймовірно, що у виробничих умовах, де спостерігаються високі рівні експозиції ( 2,56,5 мг/м³), ФА разом з прямими генотоксичними ушкодженнями здатний, як було показано [11], спричинити також оксидативний стрес, що створює умови для додаткових, опосередкованих через утворення активних форм кисню, генетичних і токсичних ушкоджень.

Накопичування цих змін у комплексі з порушеннями імунного стану за професійного впливу високих рівнів робить ФА домінуючим фактором у формуванні професійної захворюваності на РЩЗ, прикладом чого $€$ наведені дослідження E. Wong та співавторів [3].

\section{Висновки}

Механізми впливу формальдегіду на щитоподібну залозу і ендокринні органи загалом донині залишаються невивченими.

Результати проведеного аналізу свідчать про те, що ФА за інгаляційного надходження до організму здатний спричинити токсичні та генотоксичні зміни (прямо або опосередковано через утворення активних форм кисню) у віддалених від місця первинного контакту тканинах у людей і тварин (циркулюючі клітини крови, кістковий мозок), що дозволяє припустити можливість таких змін і у ЩЗ.

Експериментально доведено, що ФА у значно нижчих концентраціях $\left(0,03 ; 0,3 \mathrm{mг} / \mathrm{M}^{3}\right)$, ніж канцерогенно ефективні рівні

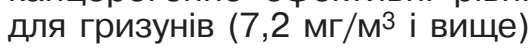
за одночасного впливу з іншими канцерогенами (бенз(а)пірен, інгаляція; 7,12-диметилбенз(а)антрацен, нашкірні аплікації) спричиняє модифікуючий ефект на канцерогенез за типом активації, який проявляється не тільки в органах, що $€$ мішенями для супутніх канцерогенів, а й у віддалених, у тому числі щ3, що не належать до мішеневих, а також посилює імунотоксичний ефект.

Имовірно, що у реальних умовах тривалого надходження ФА до організму одночасно з іншими канцерогенами атмосферного повітря та за наявності сприятливих факторів може відбуватися накопичення генотоксичних та токсичних змін у клітинах щЗ та модифікація (підсилення) сумарного ефекту (мутації, проліферація, імуносупресія) від дії комплексу хімічних ендокринних руйнівників, наслідком чого може бути зростання ризику та прискорення розвитку раку ЩЗ.

В умовах професійної експозиції на рівні високих концентрацій ФА може стати домінуючим Фактором у формуванні професійної захворюваності на рак ЩЗ.

\section{ЛІТЕРАТУРА}

1. До питання стосовно впливу канцерогенонебезпечних факторів довкілля на розвиток раку щитоподібної залози / М.В. Гульчій, С.М. Цимбалюк, І.О. Черниченко та ін. // Актуальні питання гігієни та екологічної безпеки України : зб. тез доп. наук.-практ. конф. (VIII Марзєєвські читання). - Київ, 2012. - Вип. 12. - С. 217-218.

2. Хімічні канцерогени і рак щитоподібної залози / І.О. Черниченко, О.М. Литвиченко,

С.М. Цимбалюк, М.В. Гульчій // Актуальні питання гігієни та еко- 
логічної безпекиУкраїни : зб. тез доп. наук.-практ. конф. (XI Марзєєвські читання). - Київ, 2015. - Вип. 15. - С. 175-176.

3. Reproductive history, occupational exposures and thyroid risk among women textile workers in Shanghai, China /

E.Y. Wong, R. Ray, D.L. Gao et al. // Int. Arch. Occup. Environ. Health. - 2006. - Vol. 79. P. 251-258.

4. Басков А.Я. Методология научного анализа / А.Я. Басков, Н.В. Туленков. - К. : МАУП, 2004. - 215 c.

5. Environmental and occupational medicine / W.N. Rom, ed. - Philadelfia, New-York, 1998. $1437 \mathrm{p}$.

6. Concise international chemical assessment № 40.

Formaldehyde : IPCS. - Geneva, 2002. - 98 p.

7. IARC. Monograph on the evaluation of the carcinogenic risk to humans. Formaldehyde, 2-butoxyethanol and 1-tertbutoxy-2propanol. - Lyon: IARC, 2006. - Vol. 88.

8. IARC. Monograph on the evaluation of the carcinogenic risk to humans. A review of human carcinogens: chemical agents and related occupations: Formaldehyde. - Lyon: IARC, 2012. - P. 401-431.

9. Formaldehyde exposure and leukemia: a new meta-analysis and potential mechanisms / L. Zhang, C. Steinmaus et al. // Mutat. Res. 2009. - № 681. - P. 150-168

10. Formaldehyde : IPCS / S. Costa J. Garcia-Leston, M. Coelho et al. // J. Toxicol. Environ. Health. - 2013. Vol. 76, № 4-5. - P. 217-219.

11. Bone Marrow Injury Induced via Oxidative Stress in Mice by Inhalation Exposure to Formaldehyde / Y. Zhang, X. Liu, C. McHale et al. // PLoS One. 2013. - № 8 (9). - e74974.

12. McHale C.M. Application of toxicogenomic profiling to evaluate effects of benzene and formaldehyde: from yeast to human / C.M. McHale, M.T. Smith, L. Zhang // Ann. N.Y. Acad. Sci. - 2014. № 1310 (1). - P. 74-83.

13. Субхронічний інгаляційний вплив формальдегіду на стан дихальних шляхів та імунну систему морських свинок / Б.П. Кузьмінов, Ю.В. Бісярін, Ю.Б. Кузьмінов та ін. // Медичні перспективи. - 2010.

- T. XV, № 4. - C. 114-118.

14. Patel K.G. Alteration in Thyroid after Formaldehyde
(HCHO) Treatment in Rats / K.G. Patel, H.V. Bhatt, R. Choudhury // Industrial Health. - 2003.

- № 41. - P. 295-297.

15. Закономерности модифицирующего влияния химических факторов окружающей среды на канцерогенез / А.М. Сердюк, Н.Я. Янышева, И.А. Черниченко, Н.В. Баленко // Довкілля та здоров'я. 1997. - № 2. - С. 18-22.

16. Особенности модифицирующего влияния формальдег Янышева, Н.В. Баленко, И.А. Черниченко и др. // Гигиена и санитария. - 1998. № 1. - С. 51-54.

17. Винарская Е.И. Влияние комбинированного действия бенз(а)пирена и формальдегида на иммунологическую реактивность организма / Е.И. Винарская, И.В. Кононко, Н.А. Никонова // Актуальные вопросы гигиены окружающей среды. Киев, 1995. - С. 36-38.

18. State of the Science of Endocrine Disrupting Chemicals - 2012 / WHO ; UNEP. - 2013 [Електронний ресурс]. Режим доступу: http://www. who.int/ceh/publications/endocr ine/en/

\section{REFERENCES}

1. Hulchii M.V., Tsymbaliuk S.M., Chernychenko I.O., Korzun V.N., Bahlii Ye.A. Do pytannia stosovno vplyvu kantserohenonebezpechnykh faktoriv dovkillia na rozvytok raku shchytopodibnoi zalozy [To the Issue of the Impact of

Carcinogenic Safe Environmental Factors on the Development of Thyroid Cancer]. In : Aktualni pytannia hihiieny ta ekolohichnoi bezpeky Ukrainy [Topical Issues of Hygieneand Ecological Safety of Ukraine : Conf. Materials]. Kyiv ; 2012 ; 217-218 (in Ukrainian).

2. Chernychenko I.O., Lytvychenko O.M., Tsymbaliuk S.M., Hulchii M.V. Khimichni kantseroheny i rak shchytopodibnoi zalozy [Chemical Carcinogens and Thyroid Cancer]. In : Aktualni pytannia hihiieny ta ekolohichnoi bezpeky Ukrainy [Topical Issues of Hygieneand Ecological Safety of Ukraine : Conf. Materials]. Kyiv ; 2015 ; 15 : 175-176 (in Ukrainian). 3. Wong E.Y., Ray R., Gao D.L. Wernli K.J., Li W., Fitzgibbons E.D., Feng Z., Thomas D.B., Checkoway H. Int. Arch. Occup. Environ. Health. $2006 ; 79$ : 251-258.

4. Baskov A. Ya., Tulenkov N.V. Metodologiia nauchnogo analiza [Methodology of Scientific Analysis]. Kiev ; 2004 : 215 p.
5. Rom W.N. (ed.) Environmental and Occupational Medicine. Philadelfia, New-York ; 1998 : 1437 p.

6. Concise International

Chemical Assessment № 40 Formaldehyde. Geneva : IPCS ; 2002 : 98p.

7. IARC. Monograph on the Evaluation of the Carcinogenic Risk to Humans. Formaldehyde, 2-butoxyethanol and 1-tertbutoxy-2propanol. Lyon : IARC ; 2006; 88.

8. IARC. Monograph on the Evaluation of the Carcinogenic Risk to Humans. A Review of Human Carcinogens: Chemical Agents and Related Occupations: Formaldehyde. Lyon : IARC ; 2012 : 401-431.

9. Zhang L., Steinmaus C., Eastmond D.A., Xin X.K., Smith M.T. Mutat. Res. $2009 ; 681$ : 150-168.

10. Costa S., Garcha-Lestyn J., Coelho M., Coelho P., Costa C., Silva S., Porto B., Laffon B., Teixeira J.P. J. Toxicol. Environ. Health. 2013 ; 76 (4-5) : 217-219. 11. Zhang Y., Liu X., McHale C., Li R., Zhang L., Wu Y., Ye X., Yang $X$. and Ding S. PLoS One. $2013 ; 8$ (9) : e74974.

12. McHale C.M., Smith M.T., Zhang L. Ann. N.Y. Acad. Sci. 2014; 1310 (1) : 74-83.

13. Kuzminov B.P., Bisiarin Yu.V., Kuzminov Yu.B., Zazuliak T.S., Hrushka O.I., Zazuliak I.A. Medychni perspektyvy. 2010 ; XV

(4) : 114-118 (in Ukrainian).

14. Patel K.G., Bhatt I. A. Choudhury $R$. Industrial Health. 2003 ; 41 : 295-297.

15. Serdiuk A.M., Yanysheva N.Ya., Chernichenko I.A., Balenko N.V. Dovkillia ta zdorovia. 1997 ; 2 : 18-22 (in Russian).

16. Yanysheva N. Ya., Balenko N.V., Chernichenko I.A., Litvichenko O.N., Sovertkova L.S., Babii V.F. Gigiena i sanitariia. 1998 ; 1 : $51-54$ (in Russian).

17. Vinarskaia E.I., Kononko I.V., Nikonova N.A. Vliianie kombinirovannogo deistviia benz(a) pirena i formaldegida na immunologicheskuiu reaktivnost organizma [Impact of the Combined

Effect of Benzopyrene and

Formaldehyde on the Immunological Reactivity of the Organism]. In : Aktualnye voprosy gigieny okruzhaiushchei sredy [Topical Issues of the Environmental Hygiene]. Kiev ; 1995 : 36-38 (in Russian).

18. WHO / UNEP State of the Science of Endocrine Disrupting Chemicals - 2012. Available at: http://www.who.int/ceh/publications/endocrine/en/

Надійшла до редакції 14.09.2015 